\title{
International Refugee Protection and the Primary Institutions of International Society
}

\begin{abstract}
$\underline{\text { Abstract }}$
Refugees are often considered as a source of disorder if not fundamental threat to international society. In contrast, and drawing from an English school approach, this article argues that the figure of the refugee is foundational to the constitution of both modern international society and its agent, the sovereign territorial state; hence refugee protection represents a primary institution of international society. Starting with conceptual and methodological considerations for studying primary institutions, the article then highlights the long-standing and widespread state practice of granting asylum. It is shown that on the one hand, the figure of the refugee serves to consolidate and naturalise the nation/state/territory trinity underpinning the modern state system; and on the other hand, protecting refugees plays a central role in the construction of statist self-identities as liberal, humanitarian and altruistic agents. The last section of the article turns to the politics of contestation of refugee protection, examining domestic, regional and international reactions to 'anti-refugee' policies in the United States, Hungary and Australia. The considerable amount of criticism generated by these restrictive policies, it is argued, evidence the enduring importance and relevance of refugee protection in (and for) international society.
\end{abstract}

\section{Key words:}

English school, Primary Institutions, Refugees, International Society, Migration, Humanitarianism

\section{Acknowledgements}

I would like to thank the editors of the Review of International Studies and the peer reviewers for their very detailed and helpful insights and suggestions. I am grateful to Peter Wilson for first encouraging me to pursue this research during my master studies at LSE, and for his constructive comments on different iterations of this paper. Finally, I would like to thank Emma Saint, George Lawson and Rubrick Biegon for their valuable comments on earlier drafts of this article. 
Nantermoz, Olivia. "International Refugee Protection and the Primary Institutions of International Society." Review of International Studies, vol. 46, no. 2, 2020, pp. 256-277., doi:10.1017/S0260210520000029.

\section{Biography}

Olivia Nantermoz is a PhD researcher at the London School of Economics and Political Science (UK). Her research explores the politics and practices of helping the suffering / vulnerable 'other' in international society. Her current project interrogates the combination of humanitarian and punitive sensibilities at the heart of international criminal justice-making, by examining international investigations of atrocity crimes in the context of Syria, Myanmar and Iraq.

\section{Corresponding Address}

London School of Economics and Political Science

Email: nantermo@lse.ac.uk

\section{Introduction}

1 out of 108 people worldwide is forcibly displaced today. ${ }^{1}$ Among these 68.5 million people, 25.4 million have fled to another country to seek protection, thereby becoming refugees. These ever-increasing trends of global displacement, and the recognition of the entanglement of forced migration flows with other global issues, have recently spurred a burgeoning body of International Relations scholarship on refugees. ${ }^{2}$ Most existing studies, however, portray refugees as a temporary issue and as a humanitarian problem or security threat for international society. As Nyers writes, '[t]he phenomenon of the refugee has a long history of being subsumed

\footnotetext{
1 UNHCR, Global Trends: Forced Displacement in 2018, available at: \{https://www.unhcr.org/ https://www.unhcr.org/5d08d7ee7.pdf \}, p. 4 accessed 16 January 2020.

${ }^{2}$ Alexander Betts and Gil Loescher, Refugees in International Relations (Oxford: Oxford University Press, 2011).
} 
Nantermoz, Olivia. "International Refugee Protection and the Primary Institutions of International Society." Review of International Studies, vol. 46, no. 2, 2020, pp. 256-277., doi:10.1017/S0260210520000029.

within discourses of crisis and danger'. ${ }^{3}$ The emphasis on crisis and emergency leads to privileging a 'problem-solving' approach which examines short-term, practical 'solutions' to reinstate order and normalcy in international society. ${ }^{4}$ For instance, a vast body of literature enquires into the conditions under which international cooperation is made possible in the intergovernmental refugee regime, imparting a central role to the United Nations High Commissioner for Refugees (UNHCR) to coordinate state responses to the so-called 'global refugee crisis'.

The limit of these approaches, however, is that they fail 'to examine the relationship of the refugee with the very workings of international society'. ${ }^{5}$ On the one hand, refugees are not simply an exceptional anomaly in international society; rather, their presence is bound up with the existence of an anarchical international system divided in separate territorial states. On the other hand, as I shall argue, refugees have a productive role for international society. Defined as a figure of lack, the refugee has served to consolidate and naturalise the fundamental principles on which international society relies - notably sovereignty and territoriality- while reestablishing the primacy of the nation-state. Yet so far, the analytical primacy of the

\footnotetext{
${ }^{3}$ Peter Nyers, 'Refugees, Humanitarian Emergencies, and the Politicization of Life', Refuge, 17:6 (1998), pp. 16-21 (16).

4 Robert Cox, 'Social Forces, States and World Orders: Beyond International Relations Theory' Millennium, 10:2 (1981), pp. 126-155.

5 Emma Haddad, The Refugee In International Society (Cambridge: Cambridge University Press, 2008), p. 4; see also Andrew Hurrell, 'Refugees, International Society, and Global Order', in Betts and Loescher (2011), pp. 85-104.
} 
Nantermoz, Olivia. "International Refugee Protection and the Primary Institutions of International Society." Review of International Studies, vol. 46, no. 2, 2020, pp. 256-277., doi:10.1017/S0260210520000029.

regime perspective in most scholarly writings has masked the deep entrenchment of refugee protection in the normative and institutional structure of international society. ${ }^{6}$

It is precisely this on-going and co-constitutive relationship between refugee protection and international society that this article intends to further explore. Thinking of refugees as 'not the exception but the rule', I propose to pay 'attention to those practices which work to reproduce and sustain prevailing conceptions of "normality" and "order"'. 7 To do so, I both draw from and contribute to the English school institutional literature. These scholars have long been interested in the historically created and evolving structure of shared understandings, rules, norms and practices characterising international society. ${ }^{8}$ Contrasting with the approach of liberal institutionalist scholars, the English School of International Relations has chiefly directed its attention towards the primary institutions of international society - that is, towards the more fundamental, durable sets of intersubjective understandings and shared practices aimed at the realisation of common goals in the society of states. ${ }^{9}$ Yet despite the prime importance of refugee protection for the

\footnotetext{
6 Falkner, Robert, and Barry Buzan, 'The Emergence of Environmental Stewardship as a Primary Institution of Global International Society', European Journal of International Relations, 25:1 (2019), pp. 131-55 (135).

${ }^{7}$ Nyers (1998), p. 17.

${ }^{8}$ Andrew Hurrell, 'Keeping history, law and political philosophy firmly within the English School', Review of International Studies, 27:3 (2001), pp. 489-494.

${ }^{9}$ Hedley Bull, The Anarchical Society (Columbia: Columbia University Press, 1977).
} 
Nantermoz, Olivia. "International Refugee Protection and the Primary Institutions of International Society." Review of International Studies, vol. 46, no. 2, 2020, pp. 256-277., doi:10.1017/S0260210520000029.

international community, and the recurring debates it generates worldwide, English School scholars have thus far paid scant attention to the topic.

When cursorily discussed, the figure of the refugee has been depicted as a victim of the Westphalian system of sovereign states and has been associated with the pluralist/solidarist debate. For instance, noting the absence of a world polity on the basis of which forced migrants could claim an unconditional right to asylum, Hurrell contrasts the 'hugely increased normative ambition of international society' with the absence of solidarist progress to assist to refugees. ${ }^{10}$ In a similar vein, Vincent describes refugee flows as the uneasy confrontation between the pluralist and noninterventionist world of states in which this issue arises, and the morality of mankind on which protection claims are grounded. ${ }^{11}$ Finally, Clark deplores the 'striking paradoxes' infusing the international politics of human movement, which reveal 'the contingent way in which vulnerability comes to be distributed'. 'To the extent that there is a "problem" with human movement', he notes, 'it exists only because of the impact of international society [:] issues deriving from international human movement are simply a transcription of the essentials of contemporary international society itself'.12 Vincent, Hurrell and Clark thus highlight the ways in

\footnotetext{
10 Hurrell (2011), p. 93.

${ }^{11}$ Raymond John Vincent, 'Political and Economic Refugees: Problems of Migration, Asylum and Resettlement'. Journal of Refugee Studies, 2:4 (1989), pp. 504-512 (511).

12 Ian Clark, The Vulnerable in International Society (Oxford: Oxford University Press, 2013), pp. 8788.
} 
Nantermoz, Olivia. "International Refugee Protection and the Primary Institutions of International Society." Review of International Studies, vol. 46, no. 2, 2020, pp. 256-277., doi:10.1017/\$0260210520000029.

which the evolving character of international society has shaped international understandings and attitudes towards the 'refugee problem'. They neglect, however, the extent to which refugee protection has itself played an integral role in the constitution of the modern international society, by impacting its fundamental institutional structure.

What this article proposes is to consider refugee protection not only in terms of the derived, secondary institutions designed by governments, but rather as a long-term and deep-seated normative development in international society. Hence I suggest that refugee protection represents a primary institution of modern international society.

To support this argument, this article shows that recurrent, patterned and shared social practices have developed among states to protect and assist refugees. This has been accompanied, since the twentieth century, by the development and consolidation of a common normative framework around the principle of asylum. This set of intersubjective understandings has not merely been behaviourregulating, but has rather acted at a more fundamental and more enduring level to constitute both state identities and the modern society of states itself.

This article proceeds in four stages. The first section briefly reviews the existing English School literature on primary institutions and its limits. I offer a 
Nantermoz, Olivia. "International Refugee Protection and the Primary Institutions of International Society." Review of International Studies, vol. 46, no. 2, 2020, pp. 256-277., doi:10.1017/S0260210520000029.

definition of primary institutions and reflect on questions of institutional variation and contestation. The section closes with methodological considerations when studying the emergence and consolidation of primary institutions. In the second section, I present the rich normative framework and shared practices that have emerged around refugee protection, at both the global and the sub-global (regional) level. I find that these shared practices are explicitly purposive, aimed at providing a solution to the international 'problem' created by refugees since the end of WWI. By reintegrating displaced individuals within the system of nation-states, refugee protection activities work to restore international order while preserving the current territorial political organisation of the world. The third section reveals that protecting refugees has been constitutive of both Westphalian international society and of national political communities. On the one hand, the figure of the refugee has historically been constructed in relation to a statist imagination of the world, thereby permitting to consolidate and naturalise the nation/sovereignty/territory trinity that underpins the modern state system. On the other hand, protecting refugees has been constitutive of statist identities and, especially since WWII, has participated in the redefinition of legitimate sovereignty and agency in terms of the humanitarian commitments of states. In fact, by pledging to grant asylum to the persecuted, liberal countries simultaneously reaffirm the fundamental values of freedom, human rights and justice on which they are founded. In the fourth section, 
Nantermoz, Olivia. "International Refugee Protection and the Primary Institutions of International Society." Review of International Studies, vol. 46, no. 2, 2020, pp. 256-277., doi:10.1017/S0260210520000029.

I turn to the politics of contestation of refugee protection. Reviewing three cases of so-called 'anti-refugee' policies (in Australia, Hungary and the United States) and the ensuing reactions at the domestic, regional and global level, I argue that the important criticism and controversies arising from these policies confirm the enduring relevance and importance of refugee protection in international society.

\section{Conceptualizing refugee protection as a primary institution of international society}

\section{The concept of primary institutions in English School scholarship}

The concept of primary institutions of international society is such a distinctive feature of the English School that its members have sometimes been called 'the British institutionalists'. ${ }^{13}$ Primary institutions have been said to represent the 'core idea',14 'central concept' 15 or else 'core insight' of the English School. ${ }^{16}$ Yet despite the recognition of the utmost importance of the notion, there

\footnotetext{
13 Hidemi Suganami, 'British Institutionalists, Or The English School, 20 Years On', International Relations, 17:3 (2003), pp. 253-272.

14 Barry Buzan, 'Not Hanging Separately: Responses to Dunne and Alder', Millennium, 34:1 (2005), pp. 183-94 (190).

15 Laust Schouenborg, 'A New Institutionalism? The English School As International Sociological Theory', International Relations 25:1 (2011), pp. 26-44 (27).

${ }^{16}$ Ian Clark, Hegemony In International Society (Oxford: Oxford University Press, 2011), p. 46.
} 
Nantermoz, Olivia. "International Refugee Protection and the Primary Institutions of International Society." Review of International Studies, vol. 46, no. 2, 2020, pp. 256-277., doi:10.1017/S0260210520000029.

is little agreement among scholars on the number and identity of primary institutions of international society.

In fact, until recently, little effort had been done to provide a rigorous conceptual definition of the term. Bull's seminal characterisation as a 'set of ideas and practices shaped towards the realisation of common goals', while arguably too imprecise and unqualified, remained for long as the influential understanding in the field. ${ }^{17} \mathrm{~A}$ broad consensus emerged to conceive primary institutions in opposition to what they were not: international organisations and regimes (secondary institutions), which have traditionally been the focus of liberal institutionalists.

More lately, English School theorists have paid renewed attention to the concept of primary (international) institutions. ${ }^{18}$ Buzan sought to provide a sharper definition of the concept, suggesting 'that they are relatively fundamental and

\footnotetext{
17 Bull (1977) p. 74.

${ }^{18}$ See notably Barry Buzan, From International to World Society? (Cambridge: Cambridge University Press, 2004); Kalevi J. Holsti, Taming The Sovereigns (Cambridge: Cambridge University Press, 2004), pp. 21-22; Schouenborg (2011); Peter Wilson, 'The English School Meets The Chicago School: The Case for a Grounded Theory of International Institutions', International Studies Review, 14:4 (2012), pp. 567-590; Christian Brütsch, 'Technocratic Manager, Imperial Agent, Or Diplomatic Champion? The IMF In The Anarchical Society', Review Of International Studies, 40:2 (2014), pp. 207-226; Kilian Spandler, 'The Political International Society: Change In Primary And Secondary Institutions', Review Of International Studies, 41:3 (2015), pp. 601-622; Filippo Costa-Buranelli, "'Do You Know What I Mean?' 'Not Exactly': English School, Global International Society And The Polysemy Of Institutions", Global Discourse, 5:3 (2015), pp. 499-514; Cornelia Navari, 'Primary and Secondary Institutions: Quo Vadit?', Cooperation and Conflict 51:1 (2016), pp. 121-127; Tonny Brems Knudsen, 'Solidarism, pluralism and fundamental institutional change', Cooperation and Conflict, 51:1 (2016), pp. 102-109; Charlotta Friedner Parrat, On the Evolution of Primary Institutions of International Society, International Studies Quarterly, 61:3 (2017), pp. 623-630; and Tonny Brems Knudsen and Cornelia Navari (eds), International Organization in the Anarchical Society (Palgrave Macmillan, 2019).
} 
Nantermoz, Olivia. "International Refugee Protection and the Primary Institutions of International Society." Review of International Studies, vol. 46, no. 2, 2020, pp. 256-277., doi:10.1017/S0260210520000029.

durable practices that are evolved more than designed; and that they are constitutive of actors and their patterns of legitimate activity in relation to each other'; ${ }^{19}$ Holsti ventured into the criteria evidencing the empirical existence of primary institutions; ${ }^{20}$ Schouenborg developed a 'structural functional' method to identify them; ${ }^{21}$ and Falkner and Buzan proposed a new analytical framework for studying the emergence of new primary institutions. ${ }^{22}$

Drawing on the work of these 'new institutionalists', 23 the following three criteria can be used to characterise the concept of primary institutions of international society:

i) The presence of a relatively stable set of shared principles, norms and rules that generate patterned and recurrent practices among the members of the society of states.

ii) That these practices must be purposive, based on coherent sets of ideas and/or beliefs and oriented towards the achievement of common (international) social goals.

\footnotetext{
${ }^{19}$ Barry Buzan, An Introduction To The English School Of International Relations (Cambridge: Polity, 2014), p. 176.

${ }^{20}$ Holsti (2004), pp. 21-22.

21 Schouenborg $(2011$.

22 Falkner and Buzan (2019).

23 Wilson (2012), p. 568.
} 
iii) That primary institutions must be constitutive of both actors (states) and international society.

This 'constitutive' nature of primary institutions has two aspects. On the one hand, primary institutions mould actors' identities, and thus shape the perception of their interests. ${ }^{24}$ On the other hand, primary institutions are constitutive of international society in the sense that they define the 'rules of the game', ${ }^{25}$ what counts as legitimate agency and rightful action; ${ }^{26}$ primary institutions also permit to preserve international order and the core underpinnings of the state system. ${ }^{27}$

\section{Institutional variation and the politics of contestation}

Although primary institutions are 'relatively stable' sets of intersubjective understandings and shared practices, they 'are neither permanent nor fixed'. ${ }^{28}$ Knudsen has proposed to differentiate between the constitutive principles which form the normative core of a primary institution, and the different practices through

\footnotetext{
${ }^{24}$ Alexander Wendt, 'Anarchy Is What States Make Of It: The Social Construction Of Power Politics', International Organization 46:2 (1992), pp. 391-425.

${ }^{25}$ Buzan, (2004), p. 181.

${ }^{26}$ Christian Reus-Smit, The Politics Of International Law (Cambridge: Cambridge University Press, 2004), p. 20.

27 The separability between the actors (states) and international society is admittedly contestable. According to the logic of structuration, 'there is a sense in which the state and the society of states are seen as co-constituted': see Chris Brown, 'World Society and the English School: An "International Society" Perspective on World Society', European Journal of International Relations, 7(4), pp. 423-441 (434); Buzan, (2004), p. 178. That being said, the distinction between these two aspects of the idea of constitutive institutions remains useful for analytical purposes and will thus be maintained for this research.

${ }^{28}$ Buzan (2004), pp. 181.
} 
which the institution is organised or reproduced. ${ }^{29}$ This opens the possibility for change in the working and operation of primary institutions, what Buzan terms 'changeability within a constant'. ${ }^{30}$ Institutional continuity is associated with the reproduction of constitutive principles, while institutional change relates to the modification of institutional practices, or of (non-constitutive) rules and norms. In sum, a primary institution cannot dispense itself from the constitutive principles whcih define its normative identity (their modification prompting a change of primary institution). However, the associated set of shared norms, rules and practices, although derived from the constitutive principles(s), is not immutable, and is likely to be transformed over time (reflecting changes in the primary institution itself).

Knudsen's model of institutional continuity/change can also be adapted to conceptualise sub-global level variation in the operation of a primary institution. The specific cultures, values and traditions of regional international societies may generate different institutional make-ups. ${ }^{31}$ When these rules and practices all participate in the reproduction of the same constitutive principle(s), they are best

29 Tonny B. Knudsen, 'Fundamental Institutions and International Organizations: Theorizing Continuity and Change', in Knudsen and Navari (2019), pp. 23-50 (38-40).

${ }^{30}$ Buzan (2004), pp. 178.

31 Knudsen (2019). 
Nantermoz, Olivia. "International Refugee Protection and the Primary Institutions of International Society." Review of International Studies, vol. 46, no. 2, 2020, pp. 256-277., doi:10.1017/S0260210520000029.

conceptualised as constituting the same primary institution shared by the members of international society.

Another important precision regards how to interpret contestation of the constitutive norm of a primary institution, or state practices diverging from it. Although primary institutions must be shared widely by the members of international society, they are not necessarily universally, and are always subject to contention. Contestation should thus not automatically be equated with a weakening of the global status of a primary institution. What matters is rather the reaction of other actors -domestically, regionally and globally. When non-respect for the principles and rules of a primary institution is followed by a disapproving, or even vociferous response from other members of international society, this is evidence of a widespread consensus regarding the desirability of the institution. In contrast, if deviant behaviour stays unacknowledged, or is largely met with acquiescence, this signals the contested status of a primary institution (at least at the global level).

\section{Methodological considerations}

If recent efforts to sharpen conceptualisations of primary institutions are a welcome move for the English school, they have not ended disagreements regarding 
which (of many possible) candidates belong to the set of primary institutions of international society. For Wilson, the problem lies in the insufficient empirical grounding of much work on the subject: as he notes, even tight definition of primary institutions remain open to the biases of the investigator. Yet another source of the dissensus between scholars is found in the lack of methodological discussions - and thus, the absence of clear criteria justifying the inclusion or exclusion of potential candidates from the list of primary institutions. This 'methodological quietism' is not specific to the institutional branch:32 whereas the English School is known for treasuring its eclecticism and methodological pluralism, 33 methodology 'has often been a 'bête noire' for the [School]' ${ }^{34}$

A notable exception is Buzan and Falkner's recent endeavour to advance a framework for analysing the emergence of primary institutions in international society. ${ }^{35}$ Using the case of environmental stewardship, they identify two main criteria for determining 'entry into the ranks' of primary institutions. First is the presence of 'a clearly defined value or principle applicable across international

\footnotetext{
32 Roger D. Spegele, 'Traditional Political Realism and the Writing of History', in Alex J. Bellamy (ed.), International Society and its Critics (Oxford: Oxford University Press, 2005), p. 97.

33 Andrew Linklater and Hidemi Suganami, The English School of International Relations: A Contemporary Reassessment (Cambridge: Cambridge University Press, 2006).

${ }^{34}$ Filippo Costa Buranelli, 'Explaining the Yolks: Process-tracing and the Formation of Regional International Societies' (working paper, 2015), p. 1. Discussions about English School methodology have however been reignited in more recent years: see notably Navari (2009); Buzan (2014); Costa Buranelli (2015).

${ }^{35}$ Buzan and Falkner (2019).
} 
Nantermoz, Olivia. "International Refugee Protection and the Primary Institutions of International Society." Review of International Studies, vol. 46, no. 2, 2020, pp. 256-277., doi:10.1017/S0260210520000029.

society'; and second, 'a significant degree of social consolidation' around the norm. This process of social consolidation is manifest in the establishment of international organizations reflecting the underlying norm of the primary institution; and in 'observable and significant patterns of behaviour by states in accordance with the core norm' ${ }^{36}$

Starting from this framework, I make two friendly amendments. First, I propose to regard primary institutions not as actual entities existing in the real world, but rather as ideal-types, that is, analytical constructs which help the researcher to organise and make sense of empirics. Pace Weber, ideal-types rest on the 'one-sided accentuation of one or more points of view and [on] the synthesis of a great many diffuse, discrete, more or less present and occasionally absent concrete individual phenomena, which are arranged according to those one-sidedly emphasised viewpoints into a unified analytical construct'. ${ }^{37}$ The use of ideal-types is not foreign to the English School, and many commentators have noted strong parallels between the Weberian method and the School's tripartite distinction between international system, international society and world society. ${ }^{38}$ When it comes to primary institutions however, the dominant approach appears to be a

\footnotetext{
${ }^{36}$ Ibid, pp. 135-6.

${ }^{37}$ Max Weber, The methodology of the social sciences (Free Press, 1949), p. 81.

38 See for instance Navari (2009), p. 14; Linklater and Suganami (2006), p. 103; Edward Keene, 'International Society as an Ideal Type', in Navari (2009).
} 
Nantermoz, Olivia. "International Refugee Protection and the Primary Institutions of International Society." Review of International Studies, vol. 46, no. 2, 2020, pp. 256-277., doi:10.1017/S0260210520000029.

phenomenologist and mind-world dualist one, which posits the real-world existence of primary institutions, independent of the mind of the researcher. For instance, Buzan explains that the objective is 'to describe and theorize about what goes on in the world, and in that sense it is a positivist approach, though not a materialist one.' ${ }^{39}$ In contrast, in an ideal-typic conception, primary institutions are not attempts to capture the reality in its entirety, not even to approximate it. Rather, what ideal-types do is 'to capture the significance of an aspect of reality for us' ${ }^{40}$ They provide an 'interpretive schema' against which facts-raw, unconceptualized empirical data-may be compared'. ${ }^{41}$ This results in different standards of validity. If primary institutions are regarded as ideal-types, they cannot be 'tested' or 'verified' through mere empirical observations, as per the correspondence theory of truth. ${ }^{42}$ Rather, the pertinent question is whether or not this conceptualisation is heuristically useful to capture and explain social phenomena. ${ }^{43}$

\footnotetext{
39 Buzan (2014), p. 20.

${ }^{40}$ Keene (2009), p. 107.

41 Ibid, p. 110.

42 This needs not result in pure subjectivism, ie in the affirmation that there is no material or objective reality. Norms and practices are 'in some sense, out there, as epistemically objective patterns of actions that confront agents as external realities with which to grapple'. Primary institutions, in contrast, follow a different logic, that of abstraction, thus their aim is 'not to match actual social instances, but to draw useful connections between them': Vincent Pouliot, 'Practice Tracing', in Andrew Bennett and Jeffrey T. Checkel (eds) Process Tracing: From Metaphor to Analytic Tool (Cambridge University Press, 2014), pp. 237-259 (238-39).

43 Patrick T. Jackson, The Conduct of Inquiry in International Relations : Philosophy of Science and Its Implications for the Study of World Politics (New York: Routledge, 2011), p. 115
} 
Nantermoz, Olivia. "International Refugee Protection and the Primary Institutions of International Society." Review of International Studies, vol. 46, no. 2, 2020, pp. 256-277., doi:10.1017/\$0260210520000029.

Second, I argue that the adoption of an interpretive sensibility is best suited to tracing the processes of consolidation of an institution, of its core norm and associated practices. Indeed, primary institutions do not 'cause' things to occur, nor are they manifest in purely behavioural terms (when patterns of state actions are in line with the core constitutive norm of the primary institution). Rather, as noted previously, primary institutions have constitutive effects on both states and international society, and thus have implications for shared understandings of international legitimacy. ${ }^{44}$ Capturing these constitutive effects requires paying attention to the meaning that international actors attribute to their practices and to how they interpret and attribute significance to international norms - in other words, an interpretive grasp of the context of social action. This is in line with the 'classical approach' of early English School scholars, who placed at the centre of their enquiry the self-conceptions of actors participating in international life. ${ }^{45}$

With these precisions in mind, Buzan and Falkner's framework can be amended as such: whereas the researcher cannot trace the institution itself empirically (since it does not have real-world existence), rules, norms and practices can be observed, and used as proxies to conceptualise the primary institution of refugee protection. The researcher first needs to identify the constitutive principle

\footnotetext{
44 Buzan and Falkner (2019), p. 145.

45 Wilson (2012).
} 
Nantermoz, Olivia. "International Refugee Protection and the Primary Institutions of International Society." Review of International Studies, vol. 46, no. 2, 2020, pp. 256-277., doi:10.1017/S0260210520000029.

of the institution, that is, the core principle which defines the normative identity of a primary institution. ${ }^{46}$ This constitutive principle in turn generates a set of additional rules, norms and practices which permit to operationalise the primary institution. This process of 'social consolidation', as Buzan and Falkner call it, can be examined by looking for convergent state practices and for the creation of secondary organizations. Finally, the researcher must enquire into the constitutive effects of the institution on both state identity and international society.

With regards to international refugee protection, I propose to regard the principle of asylum - that is, the obligations that states have to protect the refugees present in their territory - as the constitutive principle. Indeed, the principle of asylum provides the basis for state practices and obligations towards refugees, and (to a lesser extent) for burden sharing (the duty to assist another state in providing refugee protection). In the next two sections, I will assess whether there has been significant social consolidation around the principle of asylum in international society and examine its constitutive effects on both state identity and international society.

46 Knudsen (2019). 


\section{A dense normative framework and widespread state practice to}

\section{protect refugees}

This section briefly introduces the rich set of common norms, rules and practices that have developed, both at the global and regional level, around asylum and refugee protection. I show that these shared practices are purposive and goaloriented, designed to reintegrate the displaced people inside the society of states, and thereby to provide a solution to the international 'problem' that refugees represent.

\section{From the ancient practice of asylum to the modern institution of refugee protection}

The principle of asylum goes far back in time: human displacement has been a permanent feature of history, and similarly, practices of granting protection to the stranger exist since the most ancient civilisations. ${ }^{47}$ References to practices of helping individuals fleeing persecution have been found in texts written by the Babylonian, Hittite, Assyrian and Egyptian more than 3,500 years ago. ${ }^{48}$ The principle of asylum was originally rooted in religious commands, the three

\footnotetext{
${ }^{47}$ François Crepeau, Droit D'asile (Bruxelles: Bruylant, 1995), p. 29.

48 UNHCR, 'Protecting Refugees and the Role of UNHCR' (2014), available at: \{https://www.unhcr.org/509a836e9.pdf\} accessed 12 October 2019, p. 3.
} 
Nantermoz, Olivia. "International Refugee Protection and the Primary Institutions of International Society." Review of International Studies, vol. 46, no. 2, 2020, pp. 256-277., doi:10.1017/S0260210520000029.

monotheistic religions setting a duty of hospitality and protection to foreigners. ${ }^{49}$ The principle of asylum however progressively acquired a political nature, becoming an expression of state (territorial) sovereignty.

Historically, the evolution of asylum and refugeehood has in fact closely paralleled the emergence and consolidation of the modern state. The term 'réfugié' itself was first coined in 1685, to designate the 200, 000 French Huguenots that fled to England in fear of religious persecution..$^{50}$ Yet until the end of the nineteenth century, while many political exilés found refuge in European safe-havens, no clear distinction was made between the émigré, the exilé, the refugee or other foreigners. ${ }^{51}$ Refugees arrived in limited numbers and were not perceived as a burden for receiving societies; hence neither did they represent a problem for the state system.

Only in the twentieth century would refugees start to be apprehended as a specific subject of international concern, their protection and assistance henceforth taking a distinctive and purposive role for the society of states. ${ }^{52}$ By virtue of their

\footnotetext{
${ }^{49}$ Maria-Teresa Gil-Bazo, 'Asylum As A General Principle Of International Law', International Journal Of Refugee Law 27:1 (2015), pp. 3-28. In Ancient Greece, the duties of xenia - hospitality, or 'guestfriendship' - extended to those in exile or fleeing persecution, providing an equivalent to the principle of asylum: Elena Isayev, 'Between Hospitality and Asylum: A Historical Perspective on Displaced Agency', International Review of the Red Cross, 99:904 (2017), pp. 75-98.

${ }^{50}$ Haddad (2008).

${ }^{51}$ Christina Boswell, The Ethics Of Refugee Policy (Burlington: Ashgate, 2005), p. 23.

52 Michael Robert Marrus, The Unwanted: European Refugees In The Twentieth Century (New York: Oxford University Press, 1985).
} 
very existence, refugees pose a threat to the international system. They are 'anomalies' or 'deviations from the "normal" model of international society', ${ }^{53}$ questioning the 'givenness' and viability of the political organisation of the world into territorially bounded states. ${ }^{54}$ As noted by Agamben, 'by breaking the identity between the human and the citizen, and that between nativity and nationality, [refugees bring] the originary fiction of sovereignty to crisis'. ${ }^{55}$ They also represent a potential source of instability and security risk for other states (when they cross borders), and are therefore an international concern. ${ }^{56}$

Circa the First World War, human displacement exploded, as the attempt to reorganise the European continent into ethnically and linguistically homogenous states led to the mass expulsion of national minorities and unwanted individuals from their places of residence. ${ }^{57}$ For the League of Nations, 'the increasing influx of refugees ... endangered the stability of [countries] and was liable to provoke serious disturbances that might have affected international relations' ${ }^{58}$ Refugees could no

\footnotetext{
${ }^{53}$ Ibid, p. 7.

${ }^{54}$ Nevzat Soguk, States And Strangers (Minneapolis: University of Minnesota Press, 1999), p. 116. For an excellent analysis of how the international refugee regime centres on 'the refugee (as) problem', that is, the problems that refugees pose, as opposed to the problems which refugees face, see Natasha Saunders, International Political Theory and the Refugee Problem (Routledge 2018).

The third section will further expand on this point.

${ }^{55}$ Giorgio Agamben, Homo sacer: Sovereign power and bare life (Stanford, Calif.: Stanford University Press, 2000), pp. 20-21.

56 Gilburt Loescher, Refugee Movements And International Security (Oxford: Brassey's, 1992), pp. 4-5.

57 Soguk (1999), p. 114.

${ }^{58}$ League of Nations, Records of the Seventh Ordinary Session of the Assembly: Text of the Debates, Official Journal, special supplement 44 (1926), pp. 86-139 (113).
} 
Nantermoz, Olivia. "International Refugee Protection and the Primary Institutions of International Society." Review of International Studies, vol. 46, no. 2, 2020, pp. 256-277., doi:10.1017/S0260210520000029.

longer be seen as a matter of sovereign discretion; rather, their presence had become an international issue calling for inter-state cooperation.

In 1921, the League of Nations High Commissioner for Refugees (LNHCR) was created and tasked with clarifying the legal status of refugees and with organising their resettlement or repatriation. For the first time, the 'refugee' was constructed as a specific legal category acquiring primacy over other figures of human displacement and therefore justifying a special protection status and access to material assistance. ${ }^{59}$ This marks the important mutual recognition by states of their common obligations towards refugees: if granting asylum had previously remained a purely discretionary national practice, it henceforth became a shared imperative recognised by the members of the (then-European) international society.

Alongside the principle of asylum, an additional set of rules, norms and practices progressively emerged and consolidated. For instance, cooperation between 51 national governments enabled the creation of special identity certificates (the so-called 'Nansen passports') to allow stateless individuals and refugees to travel between countries. ${ }^{60}$ These shared practices were also, for the first time, explicitly directed towards the realisation of common (international)

\footnotetext{
${ }^{59}$ Haddad (2008), p. 203.

60 Gil Loescher, Beyond Charity: International Cooperation And The Global Refugee Crisis (Oxford University Press, 1993), p. 37.
} 
Nantermoz, Olivia. "International Refugee Protection and the Primary Institutions of International Society." Review of International Studies, vol. 46, no. 2, 2020, pp. 256-277., doi:10.1017/S0260210520000029.

social goals, namely protecting refugees, reintegrating them inside the state-system, and thereby preserving international order. The critical historical juncture of the interwar era thus arguably signals the birth, not only of an intergovernmental refugee regime, but also of the primary institution of refugee protection.

After its dissolution, the activities of the LNHCR continued under the Nansen International Office, the Intergovernmental Committee on Refugees, the United Nations Relief and Rehabilitation Agency, the International Refugee Organization until, finally, the UNHCR since $1950 .{ }^{61}$ Although the typical 'textbook' story of the modern refugee regime sees it at arising in the ashes of WWII, ${ }^{62}$ there has in fact been a remarkable similarity and continuity in the practices that have developed under these various intergovernmental refugee organisations. The 1951 Convention Relating to the Status of Refugees (hereafter '1951 Convention') replaced the previous group-oriented definitions by an individual-oriented characterisation of the refugee. ${ }^{63}$ Still, from 1921 until now, the same statist ontology has underpinned refugeehood.

\footnotetext{
61 Soguk (1999), p. 120.

62 See for instance Alexander Betts and James Milner, Governance of the Global Refugee Regime, World Refugee Council Research Paper No. 13 (2019); Alexander T. Aleinikoff and Leah Zamore The Arc of Protection: Toward a New International Refugee Regime (Stanford University Press, 2019).

63 The 1951 Convention defines a refugee as any person who, 'owing to a well-founded fear of being persecuted for reasons of race, religion, nationality, membership of a particular social group or political opinion, is outside the country of his nationality and is unable or ... unwilling to avail himself of the protection of that country' [Article 1(A)].
} 
Nantermoz, Olivia. "International Refugee Protection and the Primary Institutions of International Society." Review of International Studies, vol. 46, no. 2, 2020, pp. 256-277., doi:10.1017/S0260210520000029.

This cursory historical review suggests that international cooperation in the refugee field should not merely be conceived as the building of ad hoc, successive intergovernmental regimes. Rather, what emerged progressively was a set of shared rules and norms, defining who should be granted international protection, how states ought to offer appropriate assistance, and which solutions were to be found internationally to correct the 'abnormality' that refugees represent and to reintegrate them within the system of territorial sovereign states. These intersubjective understandings and goal-oriented shared practices are indications that, post-WWI, refugee protection became a primary institution of the European society of states.

\section{Refugee protection at present}

In the second part of the twentieth century, as membership in international society expanded across the globe, so did refugee protection globalise. The contemporary intergovernmental refugee regime was born post-WWII, with the creation of the UNHCR and the adoption of the 1951 Refugee Convention. ${ }^{64}$ While initially designed specifically for European war refugees, this legal framework

${ }^{64}$ Hedley Bull and Adam Watson (eds), The Expansion of International Society (Oxford: Clarendon, 1984). 
Nantermoz, Olivia. "International Refugee Protection and the Primary Institutions of International Society." Review of International Studies, vol. 46, no. 2, 2020, pp. 256-277., doi:10.1017/S0260210520000029.

became universal in scope with the 1967 Protocol Relating to the Status of Refugees, which removed the previous temporal and geographical limitations to the refugee definition. With respectively 145 and 146 State parties, the 1951 Convention and its Additional Protocol evidence the large consensus existing within international society to protect refugees. ${ }^{65}$ Numerous soft law declarations and resolutions have repeatedly affirmed the core importance of asylum, evidencing its nature as a general principle of international law. ${ }^{66}$ The principle of non-refoulement, another cornerstone of refugee protection, is likewise widely considered as a peremptory norm of international law. ${ }^{67}$

Yet refugee protection should not merely be regarded in terms of the international legal obligations of states, but also as a set of common intersubjective understandings which have been deeply internalised by states all over the world, shaping international relations accordingly. ${ }^{68}$ Protecting refugees has indeed become an important practice shared (quasi) universally among members of

\footnotetext{
${ }^{65}$ UN Treaties, Status of Treaties - Convention relating to the Status of Refugees, available at: \{https://treaties.un.org/pages/ViewDetailsII.aspx?src=TREATY\&amp;mtdsg_no=V-

2\&amp;chapter=5\&amp;Temp=mtdsg2\&amp;clang=_en $\}$ accessed 20 April 2019.

${ }^{66}$ Guy S. Goodwin-Gill and Jane McAdam, The Refugee In International Law (Oxford: Oxford University Press, 2007), p. 365; Gil-Bazo (2015), p. 533.

${ }^{67}$ Jean Allain, 'The Jus Cogens Nature Of Non-Refoulement', International Journal of Refugee Law 13:4 (2001), pp.553-58. Provided by article 33 of the 1951 Convention, the principle of non-refoulement forbids the return of individuals to a territory where their life or liberty would be in jeopardy, or where they would be in risk of persecution.

${ }^{68}$ Gil-Bazo (2015).
} 
Nantermoz, Olivia. "International Refugee Protection and the Primary Institutions of International Society." Review of International Studies, vol. 46, no. 2, 2020, pp. 256-277., doi:10.1017/S0260210520000029.

international society. This is particularly manifest in the commitment of states to provide asylum even in the absence of any legal obligation; and in regional-level initiatives to further cooperation for refugee protection. Below I expand on these two points.

Even in states that are not signatories to the 1951 Convention, the principle of asylum is often largely recognised and respected, evidencing its fundamental significance in international society. ${ }^{69}$ In Asia and the Pacific, only 20 of the 45 states in the region have acceded to international legal instruments protecting refugees; many governments, however, still grant temporary refuge to asylum-seekers and maintain 'their long-standing tradition of hospitality towards refugees'. ${ }^{70}$ As noted by the UNHCR, 'access to protection has been through a de facto local tradition of hospitality rather than through formalised procedures'. ${ }^{71}$ For instance,

\footnotetext{
${ }^{69}$ See for instance the Global Compact on Refugees adopted in 2018: '[i]t is recognized that a number of States not parties to the international refugee instruments have shown a generous approach to hosting refugees'. General Assembly, 'Report of the United Nations High Commissioner for Refugees - Global Compact on Refugees', A 73/12 (New York, 2018), available at:

\{https://www.unhcr.org/gcr/GCR_English.pdf\}, accessed 12 October 2019, p. 2.

70 UNHCR, 'UNHCR Global Report 2018' (2019), available at: \{http://reporting.unhcr.org/sites/default/files/gr2018/pdf/05_Asia.pdf\}, accessed 12 October 2019, p. 103.

${ }^{71}$ UNHCR, Bullet Point Summary of the Strategic Presentation on UNHCR's Operations in Asia and the Pacific, 26th Meeting of Standing Committee (2003), available at: $\{$ http://www.unhcr.org/cgibin/texis/vtx/search?page=search\&amp;docid=3e638a794\&amp;query=\%2246\%20March $\% 2020$ 03\%22\} accessed 15 April 2019.
} 
Nantermoz, Olivia. "International Refugee Protection and the Primary Institutions of International Society." Review of International Studies, vol. 46, no. 2, 2020, pp. 256-277., doi:10.1017/S0260210520000029.

notwithstanding the absence of domestic legislation on refugees, the Nepalese Supreme Court condemned in 2007 the deportation of four UNHCR-recognised Pakistani refugees. Similarly, in Mongolia, albeit the state is not a part to the 1951 Convention or the 1967 Protocol, the government 'has been pursuing a humanitarian policy in regard to asylum seekers and refugees ... and has in general respected the principle of customary international law of non-refoulement'. ${ }^{72}$ Meanwhile, in South East Asia, where there has been a lower level of internalisation of the protection norm by governments, civil society organizations have played a key role in the protection of refugees, especially regarding the provision of welfare, housing and education. As shown by Prabandari and Adiputera with the cases of Malaysia and Indonesia (the largest host country for refugees in the region), nonstates actors have created their own 'set of rules, norms and institutions, all of which constitute a form of informal governance of refugee protection'. ${ }^{73}$ Hence a de facto

\footnotetext{
72 United Nations in Mongolia, 'United Nations High Commissioner for Refugees (UNHCR)' (n.d.), available at: \{https://www.undp.org/content/unct/mongolia/en/home/agencies/unitednations-high-commissioner-for-refugees--unhcr-html\} accessed 03 October 2019. Another example is Pakistan: whereas not a party to international refugee protection instruments, the government has registered as refugees close to 900,000 undocumented Afghans in 2018. UNHCR (2019), p. 108.

${ }^{73}$ Atin Prabandari and Yunizar Adiputera, 'Alternative Paths to Refugee and Asylum Seeker Protection in Malaysia and Indonesia', Asian and Pacific Migration Journal 28:2 (2019), pp. 13254 (134).
} 
Nantermoz, Olivia. "International Refugee Protection and the Primary Institutions of International Society." Review of International Studies, vol. 46, no. 2, 2020, pp. 256-277., doi:10.1017/S0260210520000029.

protection is practiced towards refugees and asylum seekers, even in the absence of formal protection networks. ${ }^{74}$

In the Arab World, although most states have not ratified the international legal framework for refugee protection, the Islamic value of protecting 'guests' and of treating them according to the rules of hospitality serves as an important normative source explaining the commitment of governments to take asylumseekers. ${ }^{75}$ Amidst a tense context and important challenges, the UNHCR noted that in 2018, '[m] ost borders across the region remained open and asylum space was generally favourable with governments and host populations displaying commendable hospitality despite increasingly limited resources' ${ }^{76}$

These examples indicate that common, patterned and recurrent practices to protect refugees have developed (almost) universally among the members of international society, rather than exclusively in the states bound by their formal international legal obligations. Hence unlike a neorealist or neoliberalist (regime compliance) perspective, an English School approach to refugee protection gives it a deeper and more structural normative status. By illuminating patterns of similar practices, including among states which are not parties to international legal

\footnotetext{
${ }^{74}$ Ibid, p. 146.

75 Ghassan M. Arnaout, L'asile Dans La Tradition Arobo-Islamique (Genève, 1986); Musab Hayatli, 'Islam, international law and the protection of refugees and IDPs', Forced Migration Review (June 2012), p. 2.

76 See UNHRC (2019), p. 142.
} 
Nantermoz, Olivia. "International Refugee Protection and the Primary Institutions of International Society." Review of International Studies, vol. 46, no. 2, 2020, pp. 256-277., doi:10.1017/S0260210520000029.

instruments to protect refugees, the English school institutionalist perspective is best equipped to evidence how refugee protection has deeply impacted the legitimacy of international order. ${ }^{77}$

The highly symbolic value that refugee protection takes in international society is also revealed in multilateral settings, notably within the hospices of the United Nations (UN). Two initiatives are worth mentioning.

First, on $4^{\text {th }}$ December 2000, the UN General Assembly decided to create World Refugee Day, which would henceforth be celebrated every 20 June to 'honor all refugees, raise awareness and solicit support'. ${ }^{78}$ Since international days are occasions 'to mobilize political will and resources to address global problems, and to celebrate and reinforce achievements of humanity', the decision to institute an annual day of commemoration for refugees is evidence of the significance that refugee protection has in international society. ${ }^{79}$

Second, on September 2016, the 193 Member States of the UN unanimously adopted the New York Declaration for Refugees and Migrants. The Declaration - a

\footnotetext{
${ }^{77}$ I am thankful to a peer reviewer for highlighting this point; see also Buzan and Falkner (2019), p. 133.

${ }^{78}$ Earth Reminder, 'World Refugee Day - History, Themes and Quotes' (2019), available at: \{https://www.earthreminder.com/world-refugee-day/\} accessed 12 October 2019.

${ }^{79}$ UN, 'World Refugee Day 20 June' (n. d.), available at:

\{https://www.un.org/en/events/refugeeday/\}.
} 
Nantermoz, Olivia. "International Refugee Protection and the Primary Institutions of International Society." Review of International Studies, vol. 46, no. 2, 2020, pp. 256-277., doi:10.1017/S0260210520000029.

'milestone for solidarity and refugee protection at a time of unprecedented displacement across the world' 80 - expresses the profound solidarity of the international community with those who are forced to flee, and marks the recognition by Member States 'that protecting refugees and supporting the countries that shelter them are shared international responsibilities and must be borne more equitably and predictably'. 81

On top of these multilateral initiatives, important additional developments have been implemented at the regional (sub-global level) to enhance refugee protection. This is especially manifest in Africa, in Latin America and in the European Union (EU), where distinctive sets of norms, rules and practices have emerged. These regional approaches are not alternatives nor supersede what is present in the universal domain; rather, they complement and supplement it, being oriented towards the same constitutive principle of granting asylum to the persecuted or the vulnerable. Although it is beyond the scope of this paper to dress a complete account of these three regional refugee protection regimes, the cursory

80 UNHCR, 'Comprehensive Refugee Response Framework (n. d.), available at: \{https://www.unhcr.org/comprehensive-refugee-response-framework-crrf.html\} accessed 12 October 2019.

81 UNHCR, 'New York Declaration for Refugees and Migrants' (n. d.), available at: \{https://www.unhcr.org/new-york-declaration-for-refugees-and-migrants.html\} accessed 12 October 2019. 
Nantermoz, Olivia. "International Refugee Protection and the Primary Institutions of International Society." Review of International Studies, vol. 46, no. 2, 2020, pp. 256-277., doi:10.1017/S0260210520000029.

overview that will be presented aims to illustrate how the same (international) institution of refugee protection varies in its mode of reproduction and operation at the sub-global level, thereby adapting to regional specificities and needs.

Following the rapid waves of decolonisation, the 1960s witnessed an unprecedented 'flood' of African refugees. This prompted the adoption of an independent (supplementary) legal framework to deal with the specific realities of the continent. ${ }^{82}$ Ratified by 45 States as of today, the 1969 OAU Convention Governing the Specific Aspects of Refugee Problems in Africa makes three important contributions to the global refugee regime. ${ }^{83}$ Firstly, it extends the refugee definition to protect those individuals 'who, owing to external aggression, occupation, foreign domination or events seriously disturbing public order in either part or the whole of [their] country of origin or nationality', are compelled to leave their state [article 1(2)]. Secondly, the OAU Convention adopts a wide interpretation of the protection from refoulement, extending its application to include frontiers (article 2). Thirdly,

\footnotetext{
82 Jacob van Garderen and Julie Ebenstein, 'Regional Developments: Africa', in Andreas Zimmermann et al (eds), The 1951 Convention relating to the Status of Refugees and its 1967 Protocol: A commentary (Oxford: Oxford University Press, 2011), pp. 185-204.

83 African Commission on Human and Peoples' Rights, Ratification Table: AU Convention Governing Specific Aspects of Refugee Problems in Africa, available at: \{http://www.achpr.org/instruments/refugeeconvention/ratification/\} accessed 15 April 2019; Rainer Hofmann, 'Refugee law in Africa', Law and State, 39 (1989), pp. 318-333.
} 
Nantermoz, Olivia. "International Refugee Protection and the Primary Institutions of International Society." Review of International Studies, vol. 46, no. 2, 2020, pp. 256-277., doi:10.1017/S0260210520000029.

it stresses the absolute necessity of the voluntary character of any repatriation programme for refugees (article 5).

In Latin America, the 1984 Cartagena Declaration on Refugees marked the first attempt at regional collaboration and harmonisation and was subsequently complemented by the 2004 Mexican Plan of Action. The Cartagena Declaration was initially intended as a simple 'soft law' instrument. Yet over the years, as state practices have consistently aligned with its provisions, the declaration has achieved a de facto binding character in most of the region. The declaration defends a large conception of refugees encompassing all those whose lives, freedom or safety are threatened in situations of foreign aggression, internal conflict, generalised violence or massive violations of human rights. Hence the Latin American refugee protection framework has been described as 'a more comprehensive regional approach ... [centred on the] ideas of solidarity and humanitarianism'. ${ }^{84}$ The remarkably uniform application of the (extended) refugee definition in Latin America deserves emphasis, as it signals the deep internalisation by states of the common normative framework developed regionally to grant asylum.

\footnotetext{
${ }^{84}$ Flavia Piovesan and Liliana L. Jubilat, 'Regional Developments: Americas', in Zimmermann et al (2011), pp. 205-24 (224).
} 
Nantermoz, Olivia. "International Refugee Protection and the Primary Institutions of International Society." Review of International Studies, vol. 46, no. 2, 2020, pp. 256-277., doi:10.1017/S0260210520000029.

Lastly, the European Union (EU) framework is often considered as the most comprehensive regional approach for refugee protection. What started in the mid1980s as a purely intergovernmental form of cooperation has since been replaced by the increasing communautarisation and considerable harmonisation of asylum and refugee policies. In 1999, Member States pledged to establish a common asylum procedure and uniform protection status applicable throughout the EU. This led to four key Directives regulating the granting of international protection, the reception conditions of protection-seekers and the rights and minimum standards they are entitled to. ${ }^{85}$ This 'sharing of norms' has been accompanied by technical cooperation initiatives (such as Eurodac, a fingerprint database registering all migrants crossing EU borders) and mechanisms to share financial burdens (such as the European Refugee Fund and the Asylum and Integration Fund). ${ }^{86}$

As has been shown previously, the practice of asylum throughout centuries evidences its vocation of permanence. ${ }^{87}$ Yet it is only in the twentieth century that the institution of refugee protection consolidated in its modern sense. The refugee

\footnotetext{
${ }^{85}$ Council of the European Union, Council Directive 2001/55/EC of 20 July 2001, OJ L 212, 7.8.2001, p.12; Council Directive 2003/9/EC, OJ L 31, 6.2.2003, p. 18.; Council Directive 2004/83/EC of 29 April 2004, OJ L 304, 30.9.2004, p. 12; Council Directive 2005/85/EC , OJL 326, 13.12.2005, p. 13.

${ }^{86}$ Gregor Noll, "Risky Games? A Theoretical Approach To Burden-Sharing In The Asylum Field", Journal of Refugee Studies, 16:3 (2003), pp. 236-252; Eiko Thielemann, 'Towards refugee burden-sharing in the European Union: state interests and policy options', Union Studies Association Ninth Biennial International Conference (2005).

87 Gil-Bazo (2015).
} 
Nantermoz, Olivia. "International Refugee Protection and the Primary Institutions of International Society." Review of International Studies, vol. 46, no. 2, 2020, pp. 256-277., doi:10.1017/S0260210520000029.

became the subject of specific concern for the modern international society, hence requiring international cooperation. This led to the development of a rich normative framework (both at the global and regional level), coupled with repeated and consistent state practice, all directed towards a common international goal of assisting and reintegrating refugees within the existing state system.

These elements are strong signs pointing towards considering refugee protection as a primary institution of international society; however, a last condition must be now be examined: the constitutive character of primary institutions. This section mentioned that numerous states have aligned their practice with international and regional standards of refugee protection, notwithstanding the absence of formal ratification to these instruments or despite the lack of domestic legislation on asylum and refugee issues. Therefore, there are strong grounds to believe that the common principles and norms developed to protect refugees are not simply constraints on externally constituted agents; rather, they act at a more fundamental level to constitute both states and international society.

\section{Refugee protection as constitutive of the modern society of states and of national identities}

This section examines how, on the one hand, the presence of the refugee has served to reproduce and naturalise the modern state-system and the principles of 
Nantermoz, Olivia. "International Refugee Protection and the Primary Institutions of International Society." Review of International Studies, vol. 46, no. 2, 2020, pp. 256-277., doi:10.1017/S0260210520000029.

sovereignty and territoriality underpinning it; and how, on the other hand, refugee protection has participated in the constitution of statist identities, especially (though not exclusively) in liberal countries.

\section{A Critique of mainstream depictions of the refugee}

Conventional approaches to refugee protection start by taking the modern division of the world in sovereign territorial states as given and primary. The figure of the refugee is granted a secondary status, conceived as an anomaly and misfit in the society of states. From there, international refugee protection is described as a tertiary response in the face of an already existing problem, permitting to restore stability and order 'within the otherwise presumably unproblematic, stable, and secure territorial bounds of the sovereign state'. ${ }^{88}$ What I propose however to argue here, is that the refugee is everything but the marginal figure that is often depicted; rather, it has historically served to constitute the modern state system and its primary institutions of sovereignty, territoriality and national statehood.

88 Soguk (1999), p.13. For examples of such 'conventional approaches' see Louise W. Holborn, Refugees, a problem of our time: The work of the United Nations High Commissioner for Refugees, 1951-1972 (Metuchen: Scarecrow Press, 1975); Marrus (1985); Gil Loescher, The UNHCR and world politics: A perilous path (New York: Oxford University Press, 2001); Betts and Loescher, (2011). 
Nantermoz, Olivia. "International Refugee Protection and the Primary Institutions of International Society." Review of International Studies, vol. 46, no. 2, 2020, pp. 256-277., doi:10.1017/S0260210520000029.

To make this point, it is necessary to operate a critique of both refugeehood and of the state system itself. By critique I mean, in a Foucauldian perspective, to challenge 'what is, what counts as being self-evident, universal and necessary'; 89 to reveal 'on what kinds of assumptions, what kinds of familiar, unchallenged, unconsidered modes of thought' our depiction of the refugee problem rests. ${ }^{90}$ International cooperation for refugee protection should not simply be represented as a tertiary response to an external problem in the already-constituted society of states. Instead, I contend, along the lines of Soguk and Haddad, that there is a fundamental and mutually constitutive link between the refugee concept and international society'. ${ }^{91}$ Refugeehood has served practices of statecraft working to naturalise the nation/state/territory constellation on which the society of states relies.

\section{The co-constitution of the refugee and of international society}

Since the twentieth century, all successive definitions of refugees have relied on a statist ontology. Refugees' identities are conceived in negative terms, by the

\footnotetext{
${ }^{89}$ Michel Foucault, 'Why the prison?', in Graham Burchell et al (eds), The Foucault effect: Studies in governmentality; with two lectures by and an interview with Michel Foucault (Chicago: University of Chicago Press, 1991), p. 84.

${ }^{90}$ Michel Foucault, 'Practicing Criticism', in Lawrence D. Kritzman (ed) Politics, Philosophy, Culture: Interviews (New York: Routledge, 1988), p. 154.

${ }^{91}$ Soguk (1999); Haddad (2008), p. 1.
} 
Nantermoz, Olivia. "International Refugee Protection and the Primary Institutions of International Society." Review of International Studies, vol. 46, no. 2, 2020, pp. 256-277., doi:10.1017/S0260210520000029.

lack of belonging to a national community, a lack of bounded existence, a lack of 'effective state representation and protection'. ${ }^{92}$ In a world where the sovereign territorial state sets limits on the modern horizons of political imagination, dividing the world between an 'inside' and an 'outside', the refugee, who is between sovereigns, stands apart from the 'national order of things' and calls into question the inevitability and viability of national identity, of territorial boundedness and even of the state itself. ${ }^{93}$ As Ashley and Walker have shown, whereas the 'sovereign' is the place for rationality, power, order and legitimacy, that which stands outside the forcibly displaced, fleeing individual - can only become synonym of danger, disorder, anarchy and chaos. ${ }^{94}$ In fact, the very conception of refugees as moving entities immediately differentiates them from the supposed regularity of life in a sedentary, stable, fixed society. In sum, the refugee is depicted as an 'outsider' in the nation-state system. While the primacy of the nation/state/territory constellation is taken as a given, the international system from which the refugee emerges is left unquestioned. ${ }^{95}$

\footnotetext{
${ }^{92}$ Aristide R. Zolberg, 'The Formation Of New States As A Refugee-Generating Process', The Annals Of The American Academy Of Political And Social Science 467:1 (1983), pp. 24-38 (31); Soguk (1999), p. 9.

${ }_{93}$ Liisa H Malkki, Purity and Exile (Chicago: University of Chicago Press, 1995), p. 9.

${ }^{94}$ Richard K. Ashley, 'Untying the Sovereign State: A Double Reading of the Anarchy Problematique', Millennium 17:2 (1988), p. 230; Rob BJ. Walker, Inside/Outside: International Relations as Political Theory (Cambridge University Press, 1993).

${ }^{95}$ Haddad (2008), p. 48.
} 
Yet these representations are neither innocuous nor self-evident. The continuous problematisation of the refugee in statist terms has served to consolidate and stabilise representations of the sovereign territorial state, thereby constituting the modern society of states. ${ }^{96}$ Displaced bodies are instrumental in the production of a statist hierarchy, by which the territorially rooted existence of the national citizen is portrayed as the only viable model for international society, and leaving the refugee as a figure of aberration and lack.

Similarly, the granting of asylum, by 'normalizing' and regimenting the effects of mass displacement, transforms the 'refugee problem' into an affirmative resource for statecraft activities that award centrality to the pretended 'status ante', namely, the territorial political organisation of life. ${ }^{97}$ The LNHCR and its successors (until the UNHCR at present) have consistently promoted three 'durable' solutions to the refugee problem: repatriation to the home country, resettlement, or naturalisation. All three are forms of reterritorialization, aimed at correcting 'the deviation from the normal model of international society', by spatializing those

\footnotetext{
96 Soguk (1999), p. 178.

97 UNHCR, 'Statement by Mrs. Sadako Ogata, United Nations High Commissioner for Refugees, at the Roundtable Discussion on United Nations Human Rights Protection of Internally Displaced Persons', Nyon, Switzerland (1993) available at: \{http://www.unhcr.org/afr/admin/hcspeeches/3ae68fad4/statement-mrs-sadako-ogata-unitednations-high-commissioner-refugees-roundtable.html\} accessed 10 February 2020.
} 
Nantermoz, Olivia. "International Refugee Protection and the Primary Institutions of International Society." Review of International Studies, vol. 46, no. 2, 2020, pp. 256-277., doi:10.1017/S0260210520000029.

individuals 'between sovereigns'. ${ }^{98}$ Article 34 of the 1951 Refugee Convention imposes further obligations on State parties to 'facilitate the assimilation and naturalisation of refugees'. This provision seeks to restore the legal bound between the refugee and the state, confirming that the displaced individual cannot remain without a sovereign, but that his existence must be redefined in relation to a political community of national citizens. ${ }^{99}$ Refugee protection can thus be described as an attempt to transform refugees into 'quasi-citizens', by reintegrating all individuals within the nation/state/territory constellation. 100

By conceiving the refugee exclusively through spectacles productive of statist beginnings and ends, refugee protection activities posit the primacy, normalcy and permanence of a 'statized' and 'territorialised' imagination of the world. ${ }^{101}$ Thus, rather than representing a pure aberration, refugeehood is vitally productive of the nation/state/territory trinity on which the modern system of nation-states relies. In a similar vein, the processes of creating refugees - 'refugeeing'- have historically been instrumental for practices of statecraft working within the state to construct the national citizen. ${ }^{102}$

\footnotetext{
98 Haddad (2008), p. 90.

${ }^{99}$ Ibid, p. 60.

100 Ibid, p. 58.

101 Ibid, p. 256; Soguk (1999), p. 178.

102 Ibid, p. 244.
} 
Nantermoz, Olivia. "International Refugee Protection and the Primary Institutions of International Society." Review of International Studies, vol. 46, no. 2, 2020, pp. 256-277., doi:10.1017/S0260210520000029.

\section{Refugee presences as the 'vital other' for the existence of the national citizen}

States can never exist as complete and stable entities; as argued by Campbell, 103 they are always dependent on the practices of representation that permit to secure their existence. National identities are often constructed in opposition to a 'foreign', an 'outsider' or an 'enemy', and vitally depend on processes of exclusion and differentiation. ${ }^{104}$ In sum, the nation-state needs 'others' to invent an 'Us' distinct from a 'Them'. 105 Historically, human displacement has provided this indispensable 'other' serving to constitute the national community. ${ }^{106}$

In Western Europe, the emergence of the first Alien Acts (at the end of the $18^{\text {th }}$ century), and the birth of nationality laws (in the $19^{\text {th }}$ century) represented crucial moments for the codification and consolidation of national identities. As Haddad argued, 'henceforth citizen and foreigner would be correlative, mutually exclusive, exhaustive categories. One would either be a citizen or a foreigner, there would be no third way'. ${ }^{107}$ In England, the popular and stereotyped images of the

\footnotetext{
103 David Campbell, Writing Security (Minneapolis: University of Minnesota Press, 1998), p. 17.

104 Shahram Khosravi, 'The "Illegal" Traveller: An Auto-Ethnography Of Borders', Social Anthropology 15:3 (2008), pp. 321-334.

105 Julia Kristeva, Strangers To Ourselves (London: Harvester Wheatsheaf, 1991), p. 81.

${ }^{106}$ Such processes of 'othering' have historically taken many different forms, and have thus not manifested solely through the figure of the refugee. Other types of foreigners, the uncivilized or savage (during the period of colonization) and the deviant or criminal, have similarly represented important 'others' for nation-building. Still, this should not lead to underappreciate the importance of the refugee figure, who remains a pervasive and oft-discussed topic in both domestic and international politics.

${ }^{107}$ Haddad (2008), p. 56.
} 
Nantermoz, Olivia. "International Refugee Protection and the Primary Institutions of International Society." Review of International Studies, vol. 46, no. 2, 2020, pp. 256-277., doi:10.1017/S0260210520000029.

foreigner contributed to 'creations of a national character' and to the 'coalescence of a strongly-felt sense of English. . . -British national identity in the eighteenth century'. 108 The stranger has therefore represented the 'necessary supplement' to the emergence of the national citizen. ${ }^{109}$ In the $20^{\text {th }}$ century, the modern figure of the refugee permitted the consolidation of the nation-state, becoming a reference point through 'which the state-citizen relationship, bounded by territory, could be privileged'. ${ }^{110}$

This is well-illustrated by Honig's (2011) model of the pull and push relationship between the 'Us' and the 'Foreigner'.111 While the refugee first appears as a problem for the state, this 'outsider' is simultaneously used instrumentally to define the self, to constitute and demarcate our democracies. ${ }^{112}$ By issuing specific identity certificates (be they the Nansen passports under the LNHCR, or official documents granting international protection today), refugee protection activities have formalised a hierarchy by which the refugee always appears as secondary compared to the 'proper', territorially-rooted existence of the national citizen. Hence protecting refugees has served practices of statecraft integrally constitutive

${ }^{108}$ Daniel Statt, Foreigners And Englishmen (Newark: University of Delaware Press, 1995), pp. 186187.

109 Jacques Derrida, Of Grammatology (Baltimore, Johns Hopkins University Press, 1976).

110 Haddad (2008), p. 58.

${ }^{111}$ Honig, B. (2001). Democracy and the foreigner. Princeton, N.J.: Princeton University Press.

112 Maria Fotou, 'Ethics of hospitality: envisaging the stranger in the contemporary World' (PhD diss, The London School of Economics and Political Science, 2016), p. 72. 
Nantermoz, Olivia. "International Refugee Protection and the Primary Institutions of International Society." Review of International Studies, vol. 46, no. 2, 2020, pp. 256-277., doi:10.1017/S0260210520000029.

of modern nation-states, working to make people forget that their 'nationhood' or 'peoplehood' is an historically contingent process, and thus constantly in need to be re-effected. ${ }^{113}$

The argument advanced so far urges us to reconsider conventional depictions of the refugee as a self-evident, given figure of human displacement, and reveals the mutually constitutive relationship between refugeehood and international society. Refugees are an inevitable if unintended part of an international system in which political borders attempt to divide the world into sovereign territorial entities. ${ }^{114}$ Yet reciprocally, the society of states also crucially relies on refugee presences to consolidate specific statist representations of the world.

The concept of refugeehood is therefore a historically and 'politically produced effect' that has been vitally productive of the way in which we conceive both political life and our belonging to it. ${ }^{115}$ The problematisation of the refugee's identity, meanings and images in terms of the alleged primacy of the nation/state/territory constellation historically constructed and still constitutes the

\footnotetext{
113 Soguk (1999), p. 100; Richard Ashley, 'Imposing International Purpose: Notes on a Problematic of Governance', in Ersnt-Otto Cziempiel and James N. Rosenau (eds.), Global Changes and Theoretical Challenges (Lexington: Lexington Books, 1989).

${ }^{114}$ Haddad (2008), p. 219.

115 Soguk (1999), p. 255.
} 
Nantermoz, Olivia. "International Refugee Protection and the Primary Institutions of International Society." Review of International Studies, vol. 46, no. 2, 2020, pp. 256-277., doi:10.1017/S0260210520000029.

modern society of states. ${ }^{116}$ While I have shown that refugee protection activities are found all across the world, in both liberal and non-liberal states, in the former protecting refugees takes an additional layer of significance as it participates in the construction of national identities and constitutes the state as a humanitarian, rights-protecting agent. Since the end of WWII, granting asylum has indeed been a fundamental part of liberal states' commitment to promoting human rights and has served to reaffirm the fundamental values on which these states are founded, as explained below.

\section{Refugee protection and the constitution of humanitarian and liberal sovereigns}

International norms for refugee protection are not reducible to regulatory injunctions constraining the behaviour of exogenously-defined state actors. Rather, as emphasised by constructivists, in the process of institutionalisation actors acquire new identities and conceptions of self. ${ }^{117}$ In the $20^{\text {th }}$ century, states have increasingly justified the legitimacy of their claim to rule in terms of the protection of basic human rights and freedoms. ${ }^{118}$ Central to these claims has been the commitment to grant asylum to the persecuted.

\footnotetext{
116 Ibid, p. 100.

117 Wendt (1992), p. 416.

118 Christian Reus-Smit, 'Human Rights And The Social Construction Of Sovereignty', Review Of International Studies 27:4 (2001), p. 520.
} 
Nantermoz, Olivia. "International Refugee Protection and the Primary Institutions of International Society." Review of International Studies, vol. 46, no. 2, 2020, pp. 256-277., doi:10.1017/S0260210520000029.

Today, 34 countries recognise a constitutional right to asylum. ${ }^{119}$ In numerous other countries across the world, albeit not formally inscribed in the constitution, the provision of asylum has for long represented an important national tradition. Refugee protection has thus participated in the transformation and redefinition of the institution of sovereignty, which is not a self-referential value but rather an 'open construction whose meaning and practice has been continuously renegotiated, not least in relation to human rights'.120

Indeed, protecting the persecuted simultaneously serves to reaffirm the higher values (liberty, democracy, human rights, justice) on which liberal countries are founded, playing a crucial role in defining 'what a state is and what it exists for across the world'. ${ }^{121}$ As stated by the Costa Rican Supreme Court in an important 1998 judgement, the principle of asylum permits to preserve the 'fundamental values of the constitutional order, the tradition of protection of freedom of thought [and] freedom of expression' forming the basis of a democratic state resting on the rule of law. ${ }^{122}$ Therefore, proclaiming the right to asylum is always 'a statement of value, of ideals, of ... [what] one not only is but wants to believe it is' ${ }^{123}$ France

\footnotetext{
119 Gil-Bazo (2015), p. 24.

120 Buzan (2004), p. 132.

121 Gil-Bazo (2015), p. 28.

122 Ibid, p. 25.

123 Joseph Weiler, The Constitution of Europe: 'Do the New Clothes Have an Emperor?' and Other Essays on European Integration (Cambridge: Cambridge University Press, 1999).
} 
Nantermoz, Olivia. "International Refugee Protection and the Primary Institutions of International Society." Review of International Studies, vol. 46, no. 2, 2020, pp. 256-277., doi:10.1017/S0260210520000029.

recognises the right to asylum to 'anyone persecuted because of his action for freedom’ ( $§ 4$ of the Preamble). Similarly, the 1987 Nicaraguan Constitution offers protection to those 'persecuted for their fight in favour of democracy, peace, justice, and human rights' (article 47). Angola, Cape-Verde, Guinea Conakry, the Democratic Republic of Congo and Cuba all have comparable wordings in their national Constitutions. As evidenced by these various examples, asylum and refugee protection are thus constitutive of the national identities of, not merely Western states, but also of a much larger group of countries across the world which have placed liberal values at the core of their national legal orders.

Once deeply internalised and incorporated to the core of states' identities, the set of intersubjective understandings developed around refugee protection arguably attains a 'taken-for-granted' quality that makes conformance with the norm almost automatic. ${ }^{124}$ Moreover, rhetorical self-entrapment processes can pressure governments to maintain generous asylum policies, when doing otherwise would jeopardise states' ontological security (their desire to maintain stable social identities and conceptions of the self). ${ }^{125}$ Sweden for instance, having long been praised as being among the most generous European countries for refugees, has

\footnotetext{
124 Martha Finnemore and Kathryn Sikkink, 'International Norm Dynamics And Political Change', International Organization 52:4 (1998), pp. 887-917 (904).

125 Alexander Wendt, Social Theory Of International Politics (Cambridge: Cambridge University Press, 1999), p. 131.
} 
Nantermoz, Olivia. "International Refugee Protection and the Primary Institutions of International Society." Review of International Studies, vol. 46, no. 2, 2020, pp. 256-277., doi:10.1017/S0260210520000029.

presented its humanitarian policies as a core and defining part of its identity and traditions. As McCluskey has shown, the practice of asylum epitomises a 'governmentality of righteousness' that has been particularly pronounced in 'the Swedish story, with its national myth of moral exceptionalism and humanitarian superpowerfulness'. ${ }^{126}$ If more recently, far-right parties have risen while campaigning on anti-immigrant policies, McCluskey shows that seemingly contradictory practices, such welcoming and rejecting, integration and violence, solidarity and security, must not be understood as a contradiction but rather in relation. ${ }^{127}$ Indeed, 'through the governmentality of righteousness security comes to be expressed through humanitarianism, generosity and solidarity'.128

The example of Sweden confirms that protecting refugees takes a significance that goes above and beyond the assistance given to the displaced people. It is simultaneously a performance of a specific statist identity, that of a generous, rights-protecting agent, thereby reproducing a 'victim-saviour' relationship. ${ }^{129}$ As argued by Korsgaard, the function of action is self-constitution: by behaving in a

\footnotetext{
${ }^{126}$ Emma McCluskey, From Righteousness to Far Right: An Anthropological Rethinking of Critical Security Studies (McGill-Queen's University Press), p. 20.

127 Ibid, pp. 7-8.

128 Alvina Hoffmann, 'Review - From Righteousness to Far Right', e-ir (2019), available at: \{https://www.e-ir.info/2019/08/29/review-from-righteousness-to-far-right/\} accessed 29 September 2019.

${ }^{129}$ Polly Pallister-Wilkins, 'The humanitarian politics of European Border Policing: Frontex and border police in Evros', International Political Sociology, 9:1 (2015), pp. 53-69.
} 
Nantermoz, Olivia. "International Refugee Protection and the Primary Institutions of International Society." Review of International Studies, vol. 46, no. 2, 2020, pp. 256-277., doi:10.1017/S0260210520000029.

distinctive manner, states concurrently constitute their personal or practical identities. ${ }^{130}$ Offering asylum is 'always both about saving the other and saving one's sense of self, ... both other-regarding and narcissistic'. ${ }^{131}$ To borrow the words of former French Minister Bernard Cazeneuve, how you receive the oppressed reveals who you are. ${ }^{132}$ By protecting refugees, states simultaneously constitute themselves as humanitarian and liberal sovereigns. When advocating for new initiatives to solve the so-called European refugee crisis, France and Germany have stressed the need for the EU to 'act in a decisive manner that conforms to its values', and called on other Member States to put in place 'immigration policies that are worthy of what we represent'. 133 Thielemann has similarly argued that within the EU, the core principles of the refugee protection regime have 'clearly shaped the interests and identities of policy-makers over the past fifty years'.134 This confirms

130 Christine M Korsgaard, Self-Constitution (Oxford: Oxford University Press, 2009), p. 45.

${ }^{131}$ Henry Radice, 'Saving Ourselves? On Rescue and Humanitarian Action', Review of International Studies, 45:3 (2019), pp. 1-18 (10).

132 Ministère de l'Intérieur, Présentation à l'Assemblée nationale du projet de loi sur le droit d'asile (2014), available at: \{https://www.interieur.gouv.fr/fr/Archives/Archives-ministre-de-linterieur/Archives-Bernard-Cazeneuve-avril-2014-decembre-2016/Interventions-du-

ministre/Presentation-a-l-Assemblee-nationale-du-projet-de-loi-sur-le-droit-d-asile\} accessed 12 April 2019.

${ }^{133}$ Kim Willsher and Stephanie Kirchgaessner, Germany and France demand binding refugee quotas for EU members, The Guardian, 3 September 2015, available at: \{https://www.theguardian.com/world/2015/sep/03/germany-france- eu-refugee-quotasmigration-crisis\} accessed 20 April 2019.

${ }^{134}$ Eiko Thielemann, 'Between interests and norms: Explaining burden-sharing in the European Union', Journal of Refugee Studies, Vol. 16:3 (2003), pp. 253-273 (270). 
Nantermoz, Olivia. "International Refugee Protection and the Primary Institutions of International Society." Review of International Studies, vol. 46, no. 2, 2020, pp. 256-277., doi:10.1017/S0260210520000029.

that states themselves see an explicit link between their actions towards refugees and the values that define the core of their national identities.

Germany is a case in point: post-WWII, the country has defined its national identity in terms of protecting fundamental human rights and offering a safe haven to the persecuted, often prioritising asylum requirements even over internal security concerns. ${ }^{135}$ In August 2015, Angela Merkel declared that protecting refugees was an imperative of moral dignity and the pillar of universal human rights, and pledged to welcome more than one million asylum-seekers with fairness and solidarity. ${ }^{136}$ As shown by Mavelli, the emphasis on considerations of justice and empathy has contributed 'to reproduce a self-understanding of Germany as caring and committed'. ${ }^{137}$ Similarly, in the midst of the 'refugee crisis', David Cameron announced that the UK would 'live up to its moral responsibility' by resettling 20,000 refugees from Syria by 2020.138 This pledge reveals the desire to promote 'a self-understanding of Britain as just, moral and compassionate'. In fact, Mavelli

\footnotetext{
135 Christian Joppke, Immigration And The Nation-State (Oxford: Oxford University Press, 1999). 136 Thibaut Madelin, 'Réfugiés : Merkel appelle les Européens au devoir de dignité', Les Echos (2015), available at: \{https://www.lesechos.fr/31/08/2015/lesechos.fr/021292498851_refugies-- merkel- appelle-les- europeens-au- devoir-de-dignite.htm\#sf0RsHVSL5FVfZcI.99\} accessed 16 April 2019.

137 Luca Mavelli, 'Governing populations through the humanitarian government of refugees: Biopolitical care and racism in the European refugee crisis', Review of International Studies, Vol. 43:5 (2017), pp. 809-832 (811).

138 Patrick Wintor, 'UK to take up to 20,000 Syrian refugees over five years, David Cameron confirms', The Guardian (2015), available at: \{https://www.theguardian.com/world/2015/sep/07/uk-willaccept-up-to-20000-syrian-refugees-david-cameron-confirms\} accessed 12 April 2019.
} 
Nantermoz, Olivia. "International Refugee Protection and the Primary Institutions of International Society." Review of International Studies, vol. 46, no. 2, 2020, pp. 256-277., doi:10.1017/S0260210520000029.

argues that the humanitarian government of refugees simultaneously works as a biopolitical rationality directed at host populations themselves. Protecting refugees becomes a way to enhance the emotional life of the population by promoting positive forms of self-representation and self-appreciation. ${ }^{139}$

Hence in liberal democratic States, which have emphasised the importance of upholding respect for international human rights standards and refugee law, protecting refugees has been constitutive of statist identities as humanitarian and liberal sovereigns, while promoting positive self-understandings of the national people. ${ }^{140}$ This is not to say however, that the institution and practice of refugee protection have been uncontroversial or uncontested. In recent years, many have noted a 'restrictive turn' in migration policies, accompanied by the rise of populist, far-right parties campaigning on anti-immigrant policies. ${ }^{141}$ The next section briefly examines these politics of contestation.

\footnotetext{
139 Mavelli (2017), p. 812.

140 Matthew J Gibney, The Ethics And Politics Of Asylum (Cambridge: Cambridge University Press, 2004).

141 Christiane Ahlborn, 'Normative Erosion of International Refugee Protection: Back to State Security', in The Development of International Refugee Protection through the Practice of the UN Security Council (Genève : Graduate Institute Publications, 2010); Hurrell (2011), pp. 94-95.
} 
Nantermoz, Olivia. "International Refugee Protection and the Primary Institutions of International Society." Review of International Studies, vol. 46, no. 2, 2020, pp. 256-277., doi:10.1017/\$0260210520000029.

\section{The politics of contestation and their implications for the institution of}

\section{refugee protection}

The English School has used the concept of primary institutions to emphasise the common rules, norms and practices that bring states together and enable the sustenance of international order, but has paid much less attention to the politics of contestation surrounding these institutions. When mentioned, contestation has largely been seen as weakening the global status of primary institutions. For instance, Buzan notes that human rights are accepted only by the Western subset of international society, and can thus not be considered as a truly global institution. ${ }^{142}$ Meanwhile, Costa Buranelli draws attention to contested meanings of primary institutions, that is, the fact that the same institution may assume very different features across regional contexts. ${ }^{143}$ What I wish to suggest here however, is that contestation or diverging practices are not in themselves a sign of the weak or limited global standing of a primary institution. What is crucial is to examine not merely the contestation or apparent breach of the core norm of the institution, but more importantly the reaction of other actors - what I term the politics of contestation. Primary institutions indeed do not directly 'cause' certain practices, at least not in a behaviouralist sense. Rather, they provide 'a reasonably clear guide as

\footnotetext{
142 Buzan (2004; 2014).

143 Costa Buranelli (2015).
} 
Nantermoz, Olivia. "International Refugee Protection and the Primary Institutions of International Society." Review of International Studies, vol. 46, no. 2, 2020, pp. 256-277., doi:10.1017/S0260210520000029.

to what is the done thing, and what is not, in any given set of circumstances, of what can be expected and what not, and what will be tolerated and what will likely be met with a disapproving, perhaps vociferous, response'.144 In that respect, where violation of the core norms and practice of refugee protection is met with domestic and/or international outrage, this should be interpreted as a confirmation of the importance that the primary institution has in (and for) international society. Below I briefly examine the reactions generated by anti-refugee policies in Australia, Hungary and the United States. I argue that the important criticism of these policies, originating at the global, regional and domestic levels, confirms that refugee protection is indeed a long-term and deep-seated development in the institutional structure of international society.

\section{An 'illegal' and 'arbitrary' policy: Global indignation at Australia's 'Pacific}

\section{Solution'}

Since the beginning of the 2000s, successive Australian governments have implemented various policies to intercept boats of migrants arriving at sea and sent migrants and asylum seekers to offshore camps far from mainland Australia. Under

144 Peter Wilson, 'The English School's approach to international law'. In: Cornelia Navari (ed.) Theorising International Society: English School Methods (New York: Palgrave Macmillan, 2009), pp. 167-188 (168). 
the 'Pacific Solution', thousands of migrants have been detained for indefinite periods of time in what has been denounced as unsanitary and inhumane conditions, with reports of extensive physical and sexual abuse and mental suffering. ${ }^{145}$ These policies have been criticized by numerous international human rights NGOs and denounced as 'a cruel experiment in using suffering as a deterrent to seeking asylum'. ${ }^{146}$ Multiple intergovernmental bodies from within the UN system have also repeatedly condemned the Australian government's actions with regards to refugees and asylum seekers. The working group of on arbitrary detention, which forms part of the UN Human Rights Council, has (since June 2017) released five critical statements and qualified Australia's policy of indefinite incarceration of refugees and asylum seekers as 'illegal' and 'arbitrary'. 147 The UN Committee Against Torture, the UN Special Rapporteur on Torture and the UN Special Rapporteur on the Human Rights of Migrants, have all condemned Australia's

\footnotetext{
${ }^{145}$ Communique to the Office of the Prosecutor of the International Criminal Court, "The Situation in Nauru and Manus Island: Liability for crimes against humanity in the detention of refugees and asylum seekers' (2017), available at: \{https://docs.wixstatic.com/ugd/b743d9_e4413cb72e1646d8bd3e8a8c9a466950.pdf\} accessed 27 September 2019.

146 Human Rights Watch, 'Australia: Reverse Cruel Refugee Policy' (2019), available at: \{https://www.hrw.org/news/2019/01/17/australia-reverse-cruel-refugee-policy\}, accessed 27 September 2019

${ }^{147}$ Ben Doherty, 'UN body condemns Australia for illegal detention of asylum seekers and refugees, The Guardian (2019), available at: \{https://www.theguardian.com/world/2018/jul/08/un-bodycondemns-australia-for-illegal-detention-of-asylum-seekers-and-refugees\} accessed 30 September 2019.
} 
offshore processing of asylum requests. ${ }^{148}$ Since UN entities are intergovernmental bodies, tasked with representing the view of all nations and peoples in the world, these statements are particularly significant, testifying to the widespread international reprobation of Australian asylum policies.

\section{Anti-refugee politics on trial: the case of Hungary}

If the case of Australia illustrates the widespread global condemnation of anti-refugee policies, the example of Hungary demonstrates that regional organizations can similarly react to the passing of laws antithetic (or considerably restricting access) to asylum, and thereby reaffirm the importance of refugee protection at the sub-global level.

In July 2019, the European Commission decided to refer Hungary to the European Court of Justice following the passing of a new law which criminalises acts of assistance to asylum seekers and migrants, 'curtail[ing] the right to asylum in a way that is not compatible with EU or international law' and breaching the EU Charter of Fundamental Rights. ${ }^{149}$

\footnotetext{
148 Ben Doherty, 'The United Nations reiterates demand for Australia to close 'dire' detention centres', The Guardian (2019), available at: \{https://www.theguardian.com/australianews/2016/aug/13/united-nations-reiterates-demand-for-australia-to-close-dire-detentioncentres\} accessed 30 September 2019.

${ }^{149}$ European Commission, 'Commission takes Hungary to Court for criminalizing activities in support of asylum seekers and opens new infringement for non-provision of food in transit zones (2019),
} 
Nantermoz, Olivia. "International Refugee Protection and the Primary Institutions of International Society." Review of International Studies, vol. 46, no. 2, 2020, pp. 256-277., doi:10.1017/S0260210520000029.

As Hungary is exemplary of the recent rise of far-right, populist and xenophobic parties in many OECD countries, the strong condemnation by EU institutions themselves and the decision to take the country to court have an important symbolic value. They send a strong message that refugee protection is indeed a fundamental principle and practice in the EU, and that attempts by Member States to curtail the right to asylum will not be accepted.

\section{Domestic mobilisation for migrants: Rallying against Trump's xenophobic} policies

The election of Trump as US President, following his campaign on an antimigrants and anti-refugee programme promising to 'deport them all', is often seen as exemplary of the populist anti-refugee rhetoric rising in many OECD countries. ${ }^{150}$ Yet Trump's attempts to restrict access to asylum and to deport undocumented migrants has come under considerable criticism and controversy, not least domestically.

First, in response to the stepping up of arrests and deportations of undocumented migrants, numerous US cities, counties and states have adopted pro-

available at: $\{$ https://europa.eu/rapid/press-release_IP-19-4260_en.htm\} accessed 26 September 2019

150 Krsna Avila et al, 'The Rise of Sanctuary', ILRC (2018), available at: \{https://www.ilrc.org/risesanctuary\} accessed 30 September 2019, p. 1. 
migrants policies and declared that they will not take part in immigration enforcement and deportation. ${ }^{151}$ These initiatives, known as the Sanctuary Movement, are not new (starting in the 1980s in the United States), yet the movement has expanded despite - or perhaps mostly because of - the hateful, antiimmigrant rhetoric and policies adopted under the Trump Administration. According to the Immigrant Legal Resource Center (ILRC), over 400 counties had in 2018 stronger limitations on engaging in immigration enforcement activities compared to what they had a year before. ${ }^{152}$ In adopting sanctuary policies, these jurisdictions are sending 'a clear message to the residents in their communities: that they side with welcoming, not exclusion; with fair treatment, not family separation; with dignity, not detention; and with refuge, not retaliation'. ${ }^{153}$ In response, the Trump administration attempted to terminate federal funding for sanctuary jurisdictions, but such efforts have repeatedly been blocked by federal courts and deemed unconstitutional. ${ }^{154}$

Second, shortly after his arrival in office, Trump passed the infamous 'Travel Ban', attempting to ban nationals of eight (majority-Muslims) countries from entry

\footnotetext{
151 The Washington Times, 'Half of all Americans now live in 'sanctuaries' protecting immigrants', available at: \{https://www.washingtontimes.com/news/2018/may/10/half-of-americans-nowlive-in-sanctuaries/\} accessed 27 September 2019

152 Avila et al (2018), p.1.

153 Ibid, p. 29.

154 Jeremy Diamond and Euan McKirdy, 'Judge issues blow against Trump's sanctuary city order', CNN (2017), available at: \{https://edition.cnn.com/2017/11/21/politics/trump-sanctuary-citiesexecutive-order-blocked/index.html\} accessed 27 September 2019.
} 
Nantermoz, Olivia. "International Refugee Protection and the Primary Institutions of International Society." Review of International Studies, vol. 46, no. 2, 2020, pp. 256-277., doi:10.1017/S0260210520000029.

in the United States. The ban also effectively denied Syrian refugees from accessing asylum in the States. The measure was widely criticised, becoming the object of a domestic legal battle: in the next few days following Trump's executive order, 39 cases were filed in federal courts. ${ }^{155}$ The battle raised until the Supreme Court, which in 2018 authorised a third (amended) version of the executive order. Still, the amount of mobilisation against Trump's policies evidences that such measures are far from unanimously approved by the American public. In fact, when it comes to the protection of refugees and asylum seekers, a recent poll found that the overwhelming majority of Americans support measures to increase the number of judges dealing with asylum cases and to guarantee safe and sanitary conditions for asylum-seekers (82\% and $86 \%$ respectively). ${ }^{156}$

\section{Discussion and implications}

These three examples evidence the important criticism and controversies generated by anti-refugee policies, at the domestic, regional (sub-global) and global level.

155 Civil Rights Challenges To Trump Refugee/Visa Order, University of Michigan Law School, available at: $\{$ https://www.clearinghouse.net/results.php?searchSpecialCollection=44\}, accessed 30 September 2019.

156 Jennifer Rubin, 'Most Americans have rejected Trump's xenophobia', The Washington Post (2019), available at: $\{$ https://www.washingtonpost.com/opinions/2019/08/12/americans-have-rejectedtrumps-xenophobia-mostly/\} accessed 04 October 2019. 
Nantermoz, Olivia. "International Refugee Protection and the Primary Institutions of International Society." Review of International Studies, vol. 46, no. 2, 2020, pp. 256-277., doi:10.1017/S0260210520000029.

The politics of protestation around refugee protection, and their increased salience in the past few years, evidence the tensions and paradoxes, yet considerable importance, that refugee protection takes for (and in) international society. On the one hand, in a pluralist society of states, considerations for human protection are mediated and balanced with concerns for safeguarding the principles of sovereignty and territoriality - and in that sense, the principle and practice of asylum is bound to be contested. On the other hand, policies to deny the principle of asylum and / or deprive refugees from their fundamental rights are often met with huge disapproval and reprobation, testifying to the large consensus still prevailing in international society to protect and assist refugees.

The institution of refugee protection hence seems bound to stay, albeit not in the cosmopolitan version human rights advocates are calling for. Rather, what dominates is a more modest version - a state-centric institution, wherein decisions to protect and assist refugees are taken within the parameters of an international society of states animated by both pluralist and solidarist dynamics. 
Nantermoz, Olivia. "International Refugee Protection and the Primary Institutions of International Society." Review of International Studies, vol. 46, no. 2, 2020, pp. 256-277., doi:10.1017/\$0260210520000029.

\section{Conclusion: Refugee protection as a primary institution of international society}

Whereas the refugee phenomenon is often associated with a discourse of emergency, crisis and threat, this article has shown that the long-standing state practice of protecting refugees has been foundational to the constitution and evolution of international society. I have argued that the figure of the refugee is not merely order-disruptive but simultaneously generative of the modern political organization of the world in national, territorially bound sovereign states.

To make this argument, I have proposed to examine refugee protection in terms of the English school concept of primary institutions of international society. Starting with definitional and methodological considerations, I have suggested that primary institutions be regarded as ideal-types, whose conceptualisation requires an interpretive grasp of the social context. I have then presented the rich normative framework that has developed, both at the global and at the regional level, to protect refugees, evidencing the process of social consolidation around the principle of asylum. The importance of these shared norms and rules is further manifested by the patterned, recurrent practices of states to assist and grant asylum to forcibly displaced people. Yet granting asylum to refugees should not simply be regarded as a self-evident solution to an external problem faced by the society of states. Instead, this article has argued that there is a symbiotic and mutually constitutive 
Nantermoz, Olivia. "International Refugee Protection and the Primary Institutions of International Society." Review of International Studies, vol. 46, no. 2, 2020, pp. 256-277., doi:10.1017/S0260210520000029.

relationship between refugeehood and the state system. If the refugee is an inevitable product of the pluralist nation-state system, international society reciprocally vitally depends on refugee presences for its permanent re-enactment. The refugee has historically been an alibi for the existence of the state, representing the necessary 'other' or 'inclusive exclusion' indispensable for the construction of the national citizen. ${ }^{157}$ Refugee protection activities have been the locus of practices of statecraft working to re-affirm the alleged primacy of the nation/state/territory trinity. Hence refugeehood has permitted the constitution and consolidation of modern international society and of its elementary unit, the sovereign territorial state. Besides, protecting refugees has participated in the redefinition of states' national identities as liberal and humanitarian sovereigns. Granting asylum to the oppressed simultaneously serves to constitute the self as a generous, altruistic, rights-protecting statist agent; and permits to reaffirm the fundamental values of justice, liberty and human rights on which liberal states are founded.

157 Soguk (1999), p. 50; Agamben (2000). 